\title{
ANALISIS STABILITAS LONGSORAN BERDASARKAN \\ KONDISI TIPE, SIFAT FISIK DAN MEKANIK BATUAN DI KECAMATAN TELUKPANDAN \\ KABUPATEN KUTAI TIMUR, PROVINSI KALIMANTAN TIMUR.
}

\author{
Sujiman \\ Staff Pengajar Fakultas Teknik \\ Universitas Kutai Kartanegara Tenggarong \\ Kalimantan Timur. \\ Email : kasnadisujiman@gmail.com
}

\begin{abstract}
The research title is Slope Stability Analysis Based On Type, Physical And Mechanical Properties Rock In Teluk Pandan District, East Kutai Regency, East Kalimantan Province aimed to determine the lithology in the research area and to find out how the amount of slope that will be a landslide at that location.

How the research with the analysis of coring drilling results are then analyzed in the laboratory of rock mechanics to get the caracteristic of physical and mechanical properties of the rocks. Methods of data analysis using Hoek and bray methode with Rockslide software.

The results showed that in the area study has a sedimentary rock lithology fine to medium dedritus, such as claystone, siltstone and sandstone, as well as inserts are coal and shale. Based on the results of laboratory analysis of rock mechanics obtained density between 2,648 to 2,770. While the test results obtained value triaxal cohesion between (6.66 - 9:05) $\mathrm{Kg} / \mathrm{cm}^{2}$, friction angle in between (37.19-44.08) , cohesion residual $(2.72-3.10) \mathrm{Kg} / \mathrm{cm}^{2}$, residual friction angle $(27.22-32.44)^{\circ}$. While the direct shear test the cohesion of the summit between (6.66 - 9:05) Kg/ $\mathrm{cm}^{2}$, friction angle in the cohesion peak $(36.15-43.00)^{\circ}$, cohesion residual (2:22 to $3: 10) \mathrm{Kg} / \mathrm{cm}^{2}$, friction angle in the cohesion residual (37.22 $33.85)^{\circ}$. The simulation results stability of the slope stability Hoek and Bray using rockslide software, the result is that if the slope with a single slope stability, the stability of the slope is $60^{\circ}$, and if the slope with the stability of the slope overall stability of the slope is $48^{\circ}$.
\end{abstract}

Keywords: Slope Stability, rock type, rock physical properties, mechanical properties of rocks

\begin{abstract}
Abstrak
Penelitian yang berjudul Analisis Stabilitas Longsoran Berdasarkan Kondisi Tipe, Sifat Fisik dan Mekanik Batuan Di Kecamatan Telukpandan Kabupaten Kutai Timur, Propinsi Kalimantan Timur ini bertujuan untuk mengetahui litologi di daerah penelitian dan untuk mengetahui berapa besaran kemiringan lereng yang akan longsor di lokasi tersebut.

Cara penelitian dengan analisis dari hasil coring pemboran kemudian dianalisis di laboratorium mekanika batuan sehingga menghasilkan sifat fisik dan mekanik batuan tersebut. Metode analisis data menggunakan metode hoek and bray dengan software rockslide.

Hasil penelitian menunjukkan bahwa di daerah penelitian mempunyai litologi batuan sedimen dedritus halus hingga sedang, seperti batulempung, batulanau dan batupasir, serta
\end{abstract}


terdapat sisipan batubara dan serpih. Berdasarkan hasil analisis laboratorium mekanika batuan didapat berat jenis antara 2.648 hingga 2.770. Sedangkan hasil test triaxal didapat nilai kohesi antara $\left(6.66\right.$ - 9.05) Kg/cm², sudut gesar dalam antara $\left(37.19\right.$ - 44.08) ${ }^{\circ}$, kohesi residual (2.72 $3.10) \mathrm{Kg} / \mathrm{cm}^{2}$, sudut geser residual $(27.22-32.44)^{\circ}$. Sedangkan pada direct shear test kohesi puncak antara $(6.66-9.05) \mathrm{Kg} / \mathrm{cm}^{2}$, sudut geser dalam pada kohesi puncak $(36.15-43.00)^{\circ}$, kohesi residual $(2.22-3.10) \mathrm{Kg} / \mathrm{cm}^{2}$, sudut geser dalam pada kohesi residual $(37.22-33.85)^{\circ}$. Hasil simulasi stabilitas kemantapan lereng dari hoek and bray dengan menggunakan software rockslide, didapat hasil bahwa jika lereng dengan single slope maka stabilitas kemantapan lereng sebesar $60^{\circ}$, dan jika lereng dengan overall slope maka stabilitas kemantapan lereng sebesar $48^{\circ}$.

Kata kunci : Stabilitas longsoran, Tipe batuan, sifat fisik batuan, sifat mekanik batuan.

\section{Pendahuluan}

\subsection{Latar Belakang}

Pada prinsipnya tanah longsor terjadi bila gaya pendorong pada lereng lebih besar dari gaya penahan. Gaya penahan umumnya dipengaruhi oleh kekuatan batuan dan kepadatan tanah. Sedangkan gaya pendorong dipengaruhi oleh besarnya sudut kemiringan lereng, air, beban serta berat jenis tanah batuan. Ancaman tanah longsor biasanya terjadi pada bulan bulan basah, karena meningkatnya intensitas curah hujan. Musim kering yang panjang menyebabkan terjadinya penguapan air di permukaan tanah dalam jumlah besar, sehingga mengakibatkan munculnya pori-pori atau ronggarongga dalam tanah, yang mengakibatkan terjadinya retakan dan rekahan permukaan tanah. Pada waktu turun hujan, air akan menyusup ke bagian tanah yang retak sehingga dengan cepat tanah akan mengembang kembali. Pada awal musim hujan dan intensitas hujan yang tinggi biasanya sering terjadi kandungan air pada tanah menjadi jenuh dalam waktu singkat (hoek and Bray, 1974 dalam Koesnaryo.dkk., 2003).

Hujan lebat yang turun pada awal musim dapat menimbulkan longsor, karena melalui tanah rekahan tanah atau batuan air akan masuk dan terakumulasi di bagian dasar lereng, sehingga menimbulkan gerakan lateral. Dengan adanya vegetasi di permukaannya akan mencegah terjadinya tanah longsor, karena air akan diserap oleh tumbuhan dan akar tumbuhan juga akan berfungsi mengikat tanah. Lereng atau tebing yang terjal terbentuk akan memperbesar gaya pendorong (Nandy, 2007).

\subsection{Rumusan Masalah}

Rumusan masalah untuk mencapai tujuan penelitian adalah sebagai berikut :

1. Bagaimana kondisi litologi daerah penelitian

2. Berapa derajat besar kemiringan lereng yang dapat longsor di daerah penelitian.

\subsection{Tujuan Penelitian}

Tujuan penelitian kajian longsoran di Kecamatan Teluk pandan Kabupaten Kutai Timur, Propinsi Kalimantan Timur adalah :

1. Mengetahui litologi di daerah penelitian

2. Mengetahui besaran kemiringan lereng yang akan longsor di daerah penelitian.

\section{Metodologi}

\section{Waktu dan Lokasi Penelitian}

Penelitian ini dilaksanakan pada bulan Januari hingga Maret 2015, dan lokasi penelitian terdapat di Kecamatan Teluk Pandan dan sekitarnya Kabupaten Kutai Timur. Kalimantan Timur

\section{Penyelidikan Lapangan}

Massa batuan yang tersebar di alam merupakan kumpulan material yang tidak sama (heterogen). Setiap batuan/material memiliki karakteristik yang berbeda antara satu dengan lainnya.

Untuk mengetahui karakteristik massa batuan di suatu daerah tertentu, maka perlu dilakukan pengukuran atau pengamatan secara langsung terhadap material atau batuan yang ada di daerah tersebut. 
Sujiman : Analisis Stabilitas Longsoran Berdasarkan Kondisi Tipe, Sifat Fisik dan Mekanik ......

Tabel 1. Koordinat Lubang Bor

\begin{tabular}{lllccc}
\hline No. & Lubang Bor & Lokasi & Easting $(\mathbf{m})$ & Northing $(\mathbf{m})$ & Elevasi $(\mathbf{m})$ \\
\hline 1 & GEOTEKNIK & TELUK PANDAN & 25252 & 527998 & 122 \\
\hline
\end{tabular}

Penyelidikan lapangan yang telah dilakukan, bermaksud untuk mengambil sampel material batuan yang berada di areal penelitian. Sampel yang diambil berupa core dari pemboran geoteknik full coring. Setiap lapisan litologi diambil sampelnya sebagai representasi litologi di lapangan.

Metode kegiatan pemboran adalah dengan cara yaitu metode Coring. Alat bor yang digunakan adalah tipe Jacrow 175 dengan kemampuan dapat menembus lapisan batuan sampai dengan kedalaman $\pm 100-150$ $\mathrm{m}$ di bawah permukaan tanah.

Coring adalah kegiatan pemboran batubara untuk mengambil sampel lapisan batubara menggunakan core barrel dengan double tube. Dari hasil coring diperoleh contoh lapisan batuan, yang nantinya digunakan untuk analisa kualitas batubara dan analisa fisik serta analisis geomekanika.

\section{Pengujian Laboratorium}

Pengujian laboratorium dilakukan untuk mengetahui karakteristik material yang berada di lokasi penelitian. Parameter-parameter yang akan digunakan dalam pemodelan adalah sifat fisik dan sifat mekanik material (tanah/batuan). Sampel batuan untuk kajian geoteknik yang diuji di laboratorium mekanika batuan .

Jenis pengujian yang telah dilakukan adalah sifat fisik yaitu : Berat contoh asli, volume contoh, berat isi asli, kadar air, berat isi kering, berat jenis, angka pori, porositas, derajad kejenuhan dan berat isi kering, berat isi jenuh, triaxial test, Un-confined Compressive Strength (UCS), dan Geser Langsung (Shear Test).

\section{Metode Analisis Data.}

Hasil pengujian laboratorium dari lapangan yaitu uji sifat fisik, uji kuat trekan uniaksial dan uji kuat tekan triaksiak, kemudian dianalisis menggunakan metode hoek and bray (1974), dengan sistem rockslide.

\section{Hasil dan Pembahasan}

Material di alam umumnya berada dalam keadaan mantap (stabile), artinya distribusi tegangan pada material tersebut berada dalam keadaan setimbang (equilibrium). Namun bila ada aktivitas yang menyebabkan terganggunya tegangan material lereng, maka gaya-gaya yang terdapat dalam tanah atau batuan tersebut akan berusaha mencapai kesetimbangan baru dengan cara pengurangan beban, terutama dalam bentuk longsoran.

\subsection{Faktor-faktor yang mempengaruhi Kesetimbangan Lereng}

Kemantapan suatu lereng dipengaruhi oleh beberapa hal, antara lain :

\section{Geometri Lereng}

Geometri lereng yang terdiri dari kemiringan dan ketinggian sangat mempengaruhi kemantapan suatu lereng. Semakin besar kemiringan dan ketinggian lereng, maka kemantapannya semakin berkurang. Selain itu kegiatan penimbunan dan pemotongan lereng akan menyebabkan penambahan dan pengurangan beban sehingga kesetabilan material akan berubah.

2. Sifat fisik dan mekanik batuan

Sifat fisik batuan yang mempengaruhi kemantapan lereng antara lain : bobot isi (density), porositas, dan kandungan air. Sedangkan sifat mekanik batuan yang mempengaruhi kemantapan lereng antara lain : kuat tekan (UCS), kuat tarik, dan kuat geser (kohesi dan sudut geser dalam).

3. Struktur geologi dan karakteristiknya

Struktur geologi yang mempengaruhi kemantapan lereng antara lain : sesar (fault), kekar (Joint), lipatan ( fold), bidang perlipatan (bedding plane), dan rekahan (crack). Struktur geologi tersebut merupakan bidang-bidang lemah dan 
sekaligus sebagai tempat merembesnya air dan dapat menyebabkan terjadinya tension crack yang menyebabkan batuan menjadi mudah longsor.

4. Keadaan hidrologi dan hidrogeologi pada lereng tersebut

Keberadaan air, terutama air tanah (ground water) sangat mempengaruhi kemantapan suatu lereng, karena air tanah tersebut memiliki tekanan yang dikenal dengan tekanan air pori (pore water pressure) yang dapat menimbulkan gaya angkat (uplift force) yang sangat berpengaruh pada terjadinya longsor karena menurunkan kekuatan geser.

\section{Gaya-gaya luar}

Gaya-gaya dari luar yang dapat mempengaruhi kemantapan suatu lereng antara lain: getaran yang diakibatkan oleh gempa, peledakan, pembebanan dan lain-lain.

\section{Pelapukan}

Pelapukan sangat mempengaruhi kemantapan lereng. Temperatur yang cepat berubah dalam waktu yang singkat akan mempercepat proses pelapukan batuan. Untuk daerah tropis pelapukan terjadi lebih cepat. Oleh karena itu, singkapan batuan pada lereng tropis akan lebih cepat lapuk dan ini menyebabkan lereng mudah longsor.

\subsection{Kondisi Geologi Daerah Penelitian}

\section{- $\quad$ Kondisi Geologi Permukaan}

Berdasarkan peta topografi dari lokasi penelitian, terdapat variasi elevasi ketinggian berkisar antara $30-100 \mathrm{~m}$.

Kondisi morfologi bergelombang lemah hingga sedang dijumpai $100 \%$ di dalam wilayah kerja (sudut lereng $5-20^{\circ}$ ). Litologi penyusun daerah telitian adalah batuan sedimen yang didominasi oleh batupasir, batulanau dan batulempung dengan komposisi utama adalah kuarsa. Selain itu terdapat batulanau, kadang kadang hadir konglomeratan.

Struktur geologi yang dijumpai adalah sesar geser dan adanya struktur sinklin. Pola aliran di daerah penelitian dikontrol oleh tingkat resistensi batuan yang cenderung sama antar Formasi. Pola aliran yang berkembang adalah subdenditrik.

\section{- $\quad$ Kondisi Geologi Bawah Permukaan}

Kondisi litologi bawah permukaan pada Lokasi Pemboran dari bawah keatas adalah sebagai berikut : Satuan batulanau, berwarna abu-abu, kekerasan sedang, kemas terbuka, sortasi sedang, struktur perlapisan, permeabilitas sedang, kadang kadang terdapat batupasir sangat halus. Tebal satuan batuan ini adalah 9.6 meter. Diatasnya diendapkan selaras batulempung, warna abu-abu, struktur perlapisan, kekerasan sedang, silika, sortasi baik, kemas tertutup, permeabilitas buruk, ukuran butiran lempung, tebal satuan batuan ini adalah 8.70 meter.

Selanjutnya diendapkan lagi satuan batupasir, berwarna abu-abu terang, kekerasan sedang, butiran halus, struktur perlapisan, terdapat sisipan batulempung karbonan, batulempung dan batu bara, sortasi baik, kemas tertutup, permeabilitas sedang, tebal satuan batuan ini adalah 21.65 meter.

Diatas satuan batupasir terdapat satuan batulempung, tebal satuan batuan ini adalah 26.25 meter, dengan sisipan batupasir, batubara dan batulempung karbonan. Diatasnya lagi terdapat batulanau, dengan tebal

10.63 meter, dengan sisipan batubara dan batulempung karbonan. Kemudian diatasnya lagi terdapat batulempung dengan tebal 5.42 meter dengan sisipan batubara, dan batulempung karbonan.

Secara selaras diendapkan berturut turut batulanau, kemudian batupasir, batulempung lagi dan batupasir, terakhir batulempung kemudian batupasir.

- Material Pembentuk Lereng

Tipe batuan pada pemboran paling dominan adalah batulempung sebanyak $31.04 \%$, diikuti secara berurutan batulanau sebanyak $22.02 \%$, batulempung pasiran sebanyak $15.76 \%$, batulempung karbonan sebanyak $15.12 \%$, kemudian batupasir $7.28 \%$, batubara $6.80 \%$ dan soil $1.98 \%$. Tipe batuan dapat dilihat pada Tabel 2 dan Gambar 1. 
Sujiman : Analisis Stabilitas Longsoran Berdasarkan Kondisi Tipe, Sifat Fisik dan Mekanik .....

Tabel 2 Tipe batuan pada Pemboran

\begin{tabular}{llr}
\hline No. & LITOLOGI & PERSEN \\
\hline 1 & SOIL & $1.98 \%$ \\
2 & BATULEMPUNG & $31.04 \%$ \\
3 & BATULEMPUNG KARBONAN & $15.12 \%$ \\
4 & BATULANAU & $22.02 \%$ \\
5 & BATUPASIR & $7.28 \%$ \\
6 & BATUBARA & $6.80 \%$ \\
7 & BATULEMPUNG PASIRAN & $15.76 \%$ \\
\hline
\end{tabular}

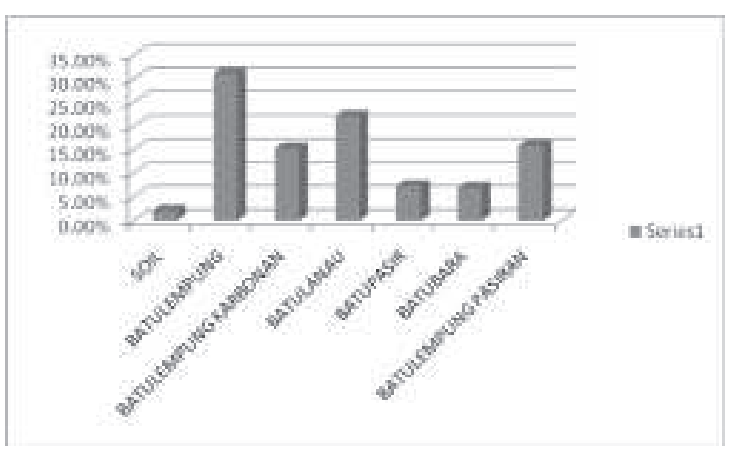

Gambar. 1 Tipe batuan pada pemboran daerah penelitian

\section{Kekuatan batuan}

Pada pemboran berdasarkan RQD (Rock Quality Designation) lapisan paling bawah mempunyai kekuatan jelek kemudian diatas lapisan batubara kekuatannya baik hingga sangat baik, selanjutnya semakin keatas keuatan batuannya sedang. Jenis litologi dan pemboran dapat dilihat pada Tabel 3

Kondisi kekuatan batuan pada lubang bor berdasarkan hasil analisis laboratorium mekanika batuan didapat berat jenis antara 2.648 hingga 2.770. Pada test triaxal test didapat kohesi total antara (6.66 - 9.05) $\mathrm{Kg} / \mathrm{cm}^{2}$, sudut gesar total antara (37.19 $44.08)^{\circ}$, kohesi residual $(2.72-3.10) \mathrm{Kg} / \mathrm{cm}^{2}$, sudut geser residual $(27.22-32.44)^{\circ}$. Sedangkan pada direct shear test kohesi puncak antara $(6.66-9.05) \mathrm{Kg} /$
Tabel 3 Jenis litologi dan RQD Pemboran

\begin{tabular}{llc}
\hline Nomor & Jenis Litologi & RQD $(\%)$ \\
\hline 1 & Batulempung & 87 \\
2 & Batupasir & $27-87$ \\
3 & Batulempung & $50-89$ \\
4 & Batupasir & $67-97$ \\
5 & Batulempung & $53-93$ \\
6 & Batupasir & 100 \\
7 & Batulempung & $33-100$ \\
8 & Batulempung karbonan & 99 \\
9 & Batupasir & 100 \\
10 & Batulempung pasiran & $90-100$ \\
11 & Batulempung karbonan & 31 \\
12 & Batulanau & $11-87$ \\
13 & Batulempung & 85 \\
14 & Batulanau & 78 \\
15 & Batubara & 100 \\
16 & Batulanau & $81-100$ \\
17 & Batulempung pasiran & $38-96$ \\
18 & Batupasir & $10-97$ \\
19 & Batubara & $57-100$ \\
20 & Batulempung & 90 \\
21 & Batulempung pasiran & 32 \\
22 & Batulempung & 32 \\
23 & Batulanau & $56-66$ \\
24 & Batulempung & 0 \\
25 & Batulanau & 0 \\
\hline & &
\end{tabular}

$\mathrm{cm}^{2}$, sudut geser dalam pada kohesi puncak (36.15 $43.00)^{\circ}$, kohesi residual $(2.22-3.10) \mathrm{Kg} / \mathrm{cm}^{2}$. sudut geser dalam pada kohesi residual $(37.22-33.85)^{\circ}$. Ini menunjukkan bahwa batuan di lokasi penelitian termasuk dalam kekuatan yang sedang.

Litologi yang ada di daerah penelitian pada umumnya adalah batuan sedimen dedritus halus hingga sedang, seperti batulempung, batulanau dan batupasir,dan terdapat sisipan batubara, serpih. Kondisi litologi hasil pemboran di Kecamatan Telukpandan Kabupaten Kutai Timur. Propinsi Kalimantan Timur dapat dilihat pada Gambar 2. 
Jurnal Bumi Lestari, Volume 16 No. 1, Pebruari 2016, hlm. 23-31

Tabel 4. Karakteristik kekuatan batuan pada pemboran

\begin{tabular}{|c|c|c|c|c|c|c|c|}
\hline \multicolumn{3}{|c|}{ No. Lab } & 1 & 2 & 3 & 4 & 5 \\
\hline \multicolumn{3}{|c|}{ Kode conto batuan } & $\mathrm{R} 13$ & $\mathbf{R} 24$ & R33 & R53 & R64 \\
\hline \multicolumn{3}{|c|}{ Klasifikasi tanah dan batu } & Zst & Sst & Zst & Sst & Sst \\
\hline \multicolumn{8}{|c|}{ KARAKTERISTIK BERAT-VOLUME } \\
\hline Kadar air & $\mathbf{W}$ & $\%$ & 5.38 & 6.84 & 4.88 & 9.75 & 5.19 \\
\hline Berat Jenis & Gs & - & 2.770 & 2.676 & 2.692 & 2.648 & 2.703 \\
\hline Berat isi asli & & $\mathrm{g} / \mathrm{cm}^{3}$ & 2.494 & 2.210 & 2.455 & 2.244 & 1.979 \\
\hline Berat isi kering & d & $\mathrm{g} / \mathrm{cm}^{3}$ & 2.366 & 2.069 & 2.340 & 2.044 & 1.881 \\
\hline Berat isi jenuh & sat & $\mathrm{g} / \mathrm{cm}^{3}$ & 2.512 & 2.296 & 2.471 & 2.272 & 2.185 \\
\hline Porositas & $\mathbf{N}$ & $\%$ & 14.56 & 22.70 & 13.05 & 22.78 & 30.40 \\
\hline Angka pori & $\mathbf{e}$ & - & 0.17 & 0.29 & 0.15 & 0.30 & 0.44 \\
\hline Derajad kejenuhan & $\mathrm{Sr}$ & $\%$ & 87.51 & 62.38 & 87.49 & 87.48 & 32.11 \\
\hline \multicolumn{8}{|c|}{ KARAKTERISTIK PLASTISITAS } \\
\hline Batas cair & LL & $\%$ & 28.31 & NP & NP & NP & 23.38 \\
\hline Batas plastis & PL & $\%$ & 15.61 & NP & NP & NP & 14.86 \\
\hline Batas susut & PI & $\%$ & 12.69 & NP & NP & NP & 8.52 \\
\hline Indeks susut & $\mathrm{SL}$ & $\%$ & 0 & NP & $\mathrm{NP}$ & $\mathrm{NP}$ & 0 \\
\hline Activity & A & $\%$ & 1.81 & $\mathrm{NP}$ & NP & NP & 1.06 \\
\hline \multicolumn{8}{|c|}{ KARAKTERISTIK GRADASI BUTIR } \\
\hline \multirow{2}{*}{\multicolumn{2}{|c|}{ 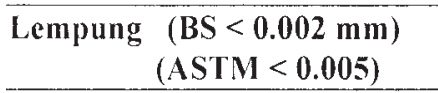 }} & $\%$ & 7 & 0 & \multirow{3}{*}{$\begin{array}{c}\text { Batuan } \\
\text { Sedimen } \\
\text { keras } \\
\end{array}$} & 0 & 8 \\
\hline & & $\%$ & 27 & 0 & & 0 & 20 \\
\hline Lanau & & $\%$ & 63 & 4 & & 4 & 32 \\
\hline \multicolumn{8}{|l|}{ Tabel 4.22 Lanjutan } \\
\hline Pasir halus & & $\%$ & 10 & 86 & \multirow{4}{*}{$\begin{array}{c}\text { Batuan } \\
\text { Sedimen } \\
\text { Keras }\end{array}$} & 91 & 21 \\
\hline Pasir sedang & & $\%$ & 0 & 0 & & 5 & 27 \\
\hline Pasir kasar & & $\%$ & 0 & 0 & & 0 & 0 \\
\hline Kerikil & & $\%$ & 0 & 0 & & 0 & 0 \\
\hline \multicolumn{8}{|c|}{ KARAKTERISTIK KEKUATAN } \\
\hline \multicolumn{8}{|c|}{ Triaxial test } \\
\hline Kohesi total & c & $\mathrm{Kg} / \mathrm{cm}^{2}$ & 8.22 & 7.28 & 9.05 & 6.66 & 7.79 \\
\hline Sudut geser total & $\Phi$ & $\ldots{ }^{0}$ & 37.19 & 44.08 & 39.28 & 43.61 & 43.57 \\
\hline Kohesi residual & cr & $\mathrm{Kg} / \mathrm{cm}^{2}$ & 2.79 & 2.54 & 3.10 & 2.32 & 2.72 \\
\hline Sudut geser residual & $\Phi$ & $\ldots$ & 27.22 & 32.44 & 29.28 & 31.72 & 32.23 \\
\hline \multicolumn{8}{|l|}{ Direct shear test } \\
\hline Kohesi puncak & сp & $\mathrm{Kg} / \mathrm{cm}^{2}$ & 8.22 & 7.28 & 9.05 & 6.66 & 7.79 \\
\hline Sudut geser total & $\Phi$ & $\ldots$ & 36.15 & 43.00 & 38.22 & 42.52 & 42.48 \\
\hline Kohesi residual & $\mathrm{cr}$ & $\mathrm{Kg} / \mathrm{cm}^{2}$ & 2.74 & 2.43 & 3.02 & 2.22 & 2.60 \\
\hline Sudut geser dalam & $\Phi$ & $\ldots$ & 27.22 & 33.85 & 29.53 & 33.41 & 33.37 \\
\hline
\end{tabular}

Catatan :

NP : Non Plastis, Cst : Batulempung. Zst : Batulanau. Sst : Batupasir 


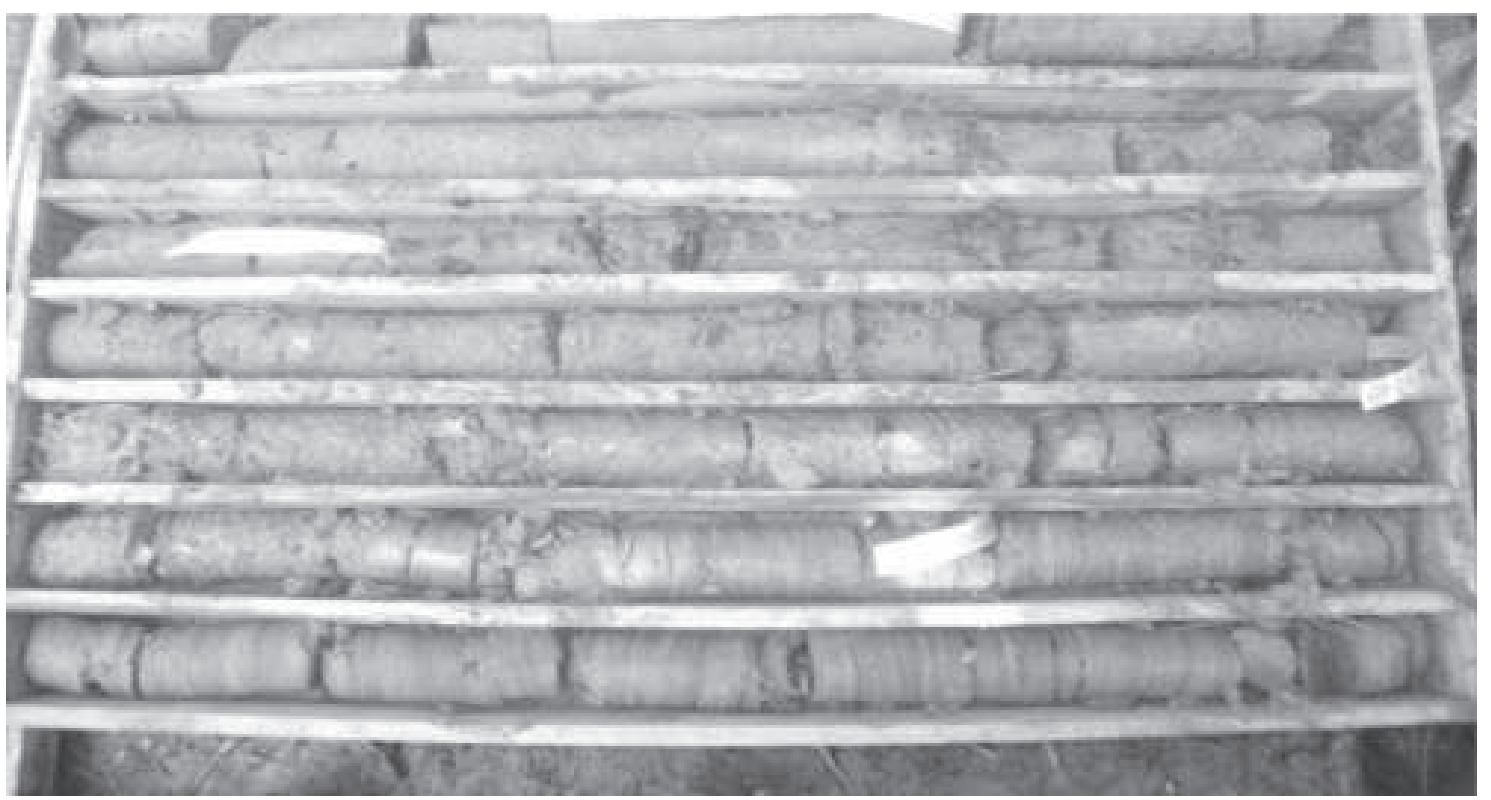

Gambar 2. Kondisi litologi hasil pemboran di Kecamatan Telukpandan Kabupaten Kutai Timur. Propinsi Kalimantan Timur.

\subsection{Analisis Dan Rekomendasi Stabilitas Lereng Daerah Penelitian}

\section{Lereng Highwall Daerah Penelitian}

a) Lereng Tunggal (Individual Slope)

Analisis kemantapan untuk lereng tunggal dilakukan dengan pendekatan sebagai Berikut :

a. $\quad$ Lereng tunggal yang akan dikaji berupa lereng yang akan terjadi longsoran.

b. Pemodelan lereng tunggal dilakukan pada masing-masing litologi dengan simulasi tinggi 10 m dengan sudut kemiringan lereng $60^{\circ}$.

c. Nilai FK (Faktor Keamanan) yang dijadikan dasar bahwa lereng dalam kondisi mantap adalah FK e" 1,30.

d. Pemodelan diaplikasikan dengan pendekatan properties rata-rata tiap litologi dalam lubang bor.

f. hasil simulasi dapat dilihat pada Gambar 3

\section{Lereng Keseluruhan (Overall Slope)}

Pendekatan untuk melakukan analisis lereng keseluruhan yang direpresentasikan oleh properties pada hasil simulasi slope stability lubang pemboran dengan tujuan untuk menyederhanakan berbagai macam parameter adalah sebagai berikut.

a. Lereng keseluruhan yang akan dikaji berupa lereng yang akan terjadi longsoran.

b. Pemodelan lereng keseluruhan dilakukan pada masing-masing cross section yang terdapat pemboran geoteknik dengan mengambil setiap satuan batuan yang ada di daerah penelitian.

c. Lereng keseluruhan sesuai dengan rekomendasi yaitu pada lokasi pemboran dengan sudut $48^{\circ}$ untuk semua material jenis batuan.

d. Nilai FK (Faktor Keamanan) yang dijadikan dasar bahwa lereng dalam kondisi mantap adalah FK e" 1,30.

e. Input data model dengan pendekatan propertis litologi rata-rata pada lubang bor.

f. Analisis pada kondisi tinggi lereng tunggal 10 meter dengan berm 3 meter.

g. Hasil simulasi dapat dilihat pada Gambar 3 . 


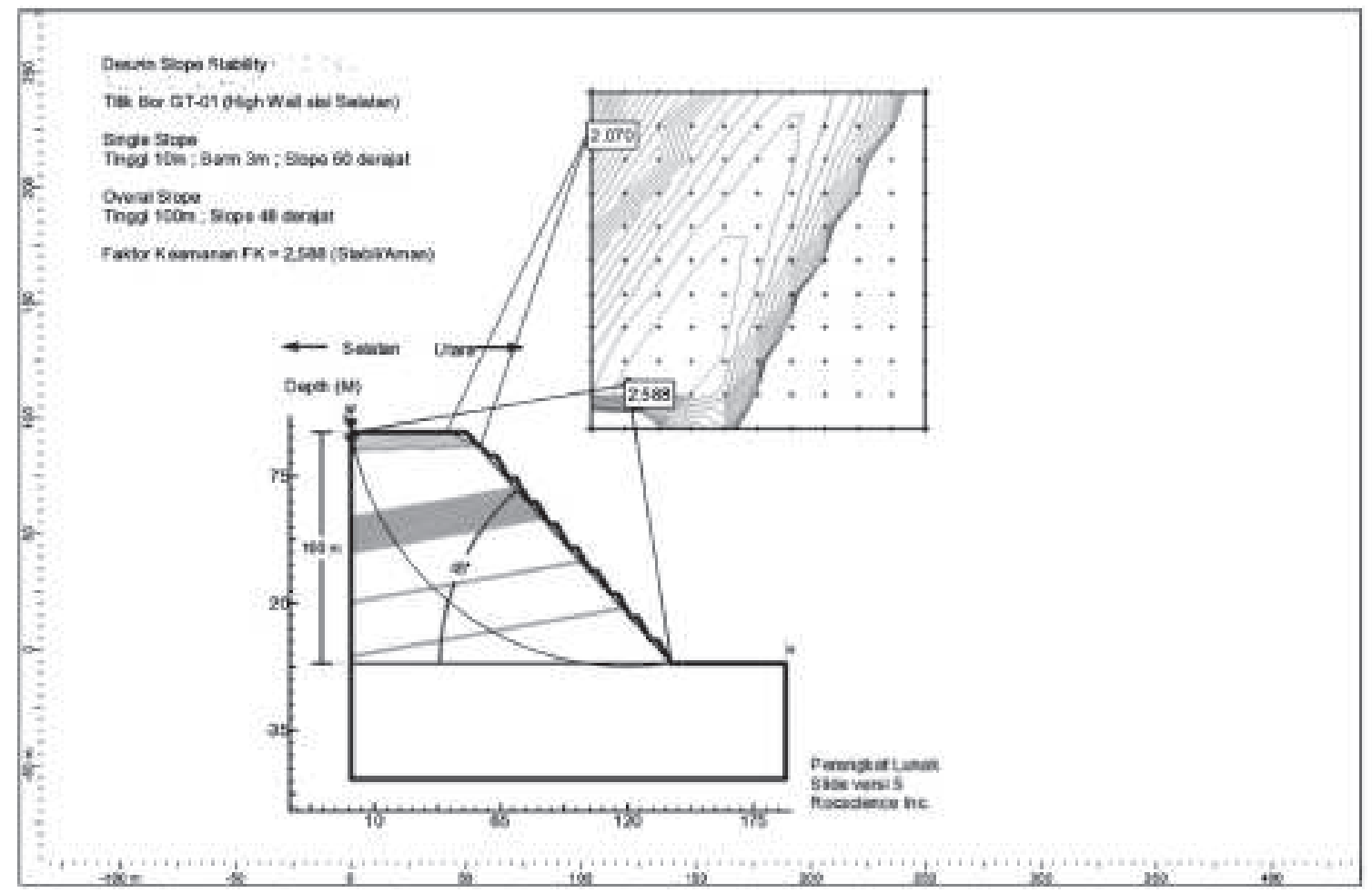

Gambar 3. Hasil simulasi slope stability bor

\section{Simpulan}

Penelitian yang berlokasi di Kecamatan Teluk Pandan Kabupaten Kutai Timur Propinsi Kalimantan Timur, ini mempunyai kesimpulan sebagai berkikut :

1. Dari hasil pemboran yang dilakukan diketahui bahwa batuan-batuan yang menyusun daerah penelitian adalah batuan-batuan sedimen berbutir pasir sedang sampai dengan berbutir sangat halus (lempung). Sedangkan berdasarkan RQD (Rock Quality Designation) lapisan batuannya adalah batuan yang mempunyai kekuatan sedang hingga baik, tetapi kadang kadang kekuatannya rendah.

2. Hasil analisis kemantapan lereng di daerah lokasi penelitian, dengan lereng tunggal dan dilakukan pada lapisan batuan yang ada, maka didapat tinggi lereng $10 \mathrm{~m}$ dan sudut kemiringan lereng $60^{\circ}$ dengan faktor keamanan 1.30. Tetapi untuk lereng keseluruhan (overall slope) tinggi lereng $100 \mathrm{~m}$ dengan sudut kemiringan lereng $48^{\circ}$ serta berm 3 meter, untuk semua lapisan batuan dengan faktor keamanan 2,588 .

\section{Daftar Pustaka}

Aprilla F., dkk., 2014. Analisis Tipe Longsoran dan Kestabilan Lereng Berdasarkan Orientasi Struktur Geologi di Dinding Utara Tambang Batu Hijau,Sumbawa Barat. 1 Jurusan Teknik Geologi, Universitas Gadjah Mada, Indonesia. Seminar Nasional Kebumian Ke-7 dan Simposium Pendidikan Geologi Nasional. Jurusan Teknik Geologi, Fakultas Teknik, Universitas Gadjah Mada, Yogyakarta, 30-31 Oktober 2014. P. 1-15.

Chambers, J. L. C, \& Daley, T., 1995. A Tectonic Model for The Onshore Kutai Basin, East Kalimantan, Based On An Integrated Geological and Geophysical Interpretation. Indonesian Petroleum Association, Proceedings 24th annual convention, Jakarta, (I):111-130.

Clay K., Dooley T., Ferguson A., Poblet J., June 2000. Tectonic Evolution of Sanga-Sanga Block Mahakam Delta Kalimantan Indonesia, $A A P G$ Bulletin, 16(6):765-786 
Fetter.,C.W., 1994. Applied Hydrogeology. Third Edition. University of Wisconsin. Oshkosh. Prentice Hall. Englewood Cliffs. New Jersey 07632.

Gordon H. Wood, et all., 1988. Coal Resource Classification System of The United State Geological Survey, Circular p. 891.

Hall, R., 2001. Cenozoic Reconstructions of SE Asia and The SW Pacific : Changing Pattern of Land and Sea, Proceeding IPA 27 Annual Convention, p.153-184

Koesnaryo., Hariyanto. R, Widodo. P., 2003. Mekanika Batuan Untuk Rekayasa Pertambangan, Jurusan Teknik Pertambangan, Fakultas Teknologi Mineral, Universitas Pembangunan Nasional "Veteran" Yogyakarta. p.1-61.
Nandi., 2007. Longsor. Jurusan Pendidikan Geografi. Fakultas Pendidikan Ilmu Pengetahuan Sosial. UPI. Bandung. p.1-45.

Notosiswoyo. S., Prodjosumarto. P., 1964., Pengantar Analisis Kemantapan Lereng, Diktat Kuliah, Jurusan Teknik Pertambangan, Fakultas teknologi Mineral, ITB Bandung. P.1-76.

Rai. M. A., 1993. Analisis Kemantapan Lereng Pit Design. Disajikan dalam Kursus Perencanaan Tambang, Direktorat Pertambangan Umum, Pusat Pengembangan Tenaga Pertambangan. p.1-98.

Supriatna, Sukardi, Rustandi, Peta Geologi Lembar Samarinda Skala $1: 250.000$, PPPG Bandung, 1994. 